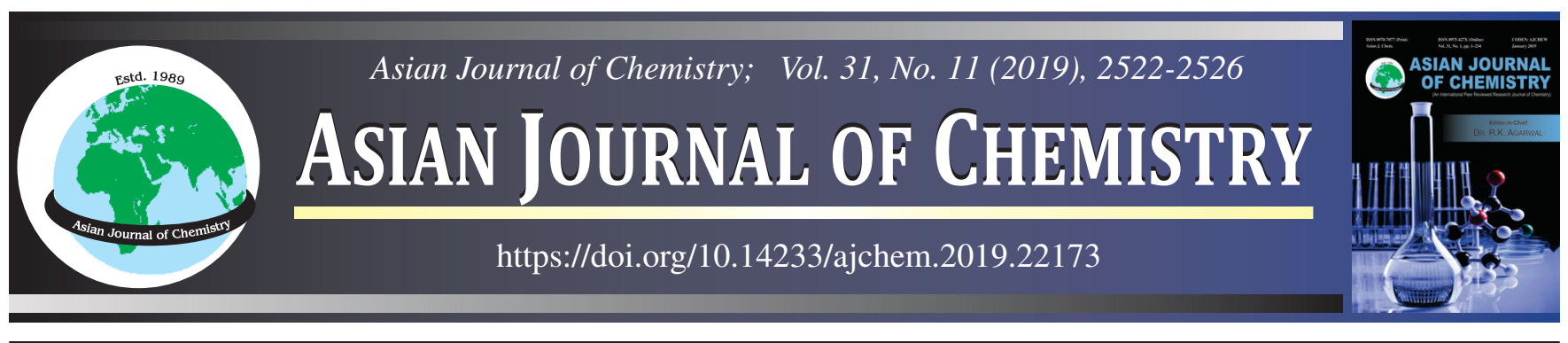

\title{
A Simple and Rapid Transformation of Golden Apple Snail (Pomacea canaliculata) Shells to Calcium Carbonate, Monocalcium and Tricalcium Phosphates
}

\section{S. Seesanong ${ }^{1}$, C. Laosinwattana ${ }^{1}$, K. Chaiseeda $^{2, \bullet}$ and B. Boonchom ${ }^{3,4, *, \bullet}$}

${ }^{1}$ Department of Plant Production Technology, Faculty of Agricultural Technology, King Mongkut's Institute of Technology Ladkrabang, Bangkok 10520, Thailand

${ }^{2}$ Department of Chemistry, Faculty of Science, King Mongkut's University of Technology Thonburi, Thung Khru, Bangkok 10140, Thailand ${ }^{3}$ Advanced Functional Phosphate Material Research Unit, Department of Chemistry, Faculty of Science, King Mongkut's Institute of Technology Ladkrabang, Bangkok 10520, Thailand

${ }^{4}$ Municipal Waste and Wastewater Management Learning Center, Faculty of Science, King Mongkut's Institute of Technology Ladkrabang, Bangkok 10520, Thailand

*Corresponding author: Fax: +66 2329 8412; Tel.: +66 23298400 ext. 8411; E-mail: kbbanjon@ gmail.com

This study was designed to manage golden apple snail shells, the wastes created in large amount daily from the consumption of the meat of golden apple snail (Pomacea canaliculata) shells by transforming them to advanced compounds; calcium carbonate $\left(\mathrm{CaCO}_{3}\right)$, monocalcium phosphate monohydrate $\left[\mathrm{Ca}\left(\mathrm{H}_{2} \mathrm{PO}_{4}\right)_{2} \cdot \mathrm{H}_{2} \mathrm{O}\right]$, and tricalcium phosphate $\left[\mathrm{Ca}_{3}\left(\mathrm{PO}_{4}\right)_{2}\right]$. They were successfully prepared by a rapid, simple, environmentally benign method using easily available and low-cost instrument. All synthesized samples were characterized by X-ray fluorescence, X-ray powder diffraction, FTIR spectroscopy and scanning electron microscopy to confirm the identities with the standard materials. The reproducibility and low-cost method suggest that it could be used in industry for a large-scale production of calcium carbonate, monocalcium phosphate monohydrate and tricalcium phosphate from golden apple snail shells as a replacement of natural mineral resources and be a good way to manage these shell wastes.

Keywords: Calcium carbonate, Monocalcium phosphate monohydrate, Tricalcium phosphate, Golden apple snail shell, $P$. canaliculata. ᄂ - - - - - - - - - - - - - - - - - - - - - - - - - - - - - - -

\section{INTRODUCTION}

Originally from South America, golden apple snail (Pomacea canaliculata), shells known in Thailand as "Hoy Cherry", has become an aggressively invasive species since its introduction into Thailand and other Asian countries as food and part of the aquarium trade. It grows and reproduces very fast and one snail can lay 300-3000 eggs per month with $80 \%$ hatchery in 7-14 days, which have widely distributed in all types of temporary and permanent water bodies such as ponds, canals and ditches, etc. [1,2]. Golden apple snail destroys rice crops and spreads rapidly over the rice fields around Thailand each year. However, there are also benefits of golden apple snail. It can be used as fertilizer, sources of food, animal feed and seasoning spices.

At present, some Thai farmers have operated golden apple snail farms because golden apple snail's meats are popular foods for Thai people and are used as feed for poultry farms [1,3]. Their meats are sold at Talad Thai Market in Pathum Thani province about 50 tons per week. When $1 \mathrm{~kg}$ of golden apple snail's meats are consumed, their shells are generated as solid wastes at about $200 \mathrm{~g}$, thus the produced wastes can be evaluated as being around 10 tons per week [4-7]. Every day many golden apple snail shells are being dumped away, causing serious environmental issues including unpleasant smell, insects, noise, and abrasiveness of these shells. Although, several studies have been done and reported about transferring golden apple snail shells to animal feed additive, soil conditioner, lime and bricks due to its rich content of calcium carbonate $\left(\mathrm{CaCO}_{3},>95 \%\right)$ $[7,8]$, the remaining larger portions of golden apple snail shells are reported to increase the solid wastes because they are generated daily in large quantity. Considering golden apple snail shells, their main content is calcium carbonate that is similar to natural lime. Thus, they can be used as raw materials for

This is an open access journal, and articles are distributed under the terms of the Attribution 4.0 International (CC BY 4.0) License. This license lets others distribute, remix, tweak, and build upon your work, even commercially, as long as they credit the author for the original creation. You must give appropriate credit, provide a link to the license, and indicate if changes were made. 
producing advanced calcium compounds. Recently, some researchers have studied the preparations of different calcium carbonate phases (aragonite, calcite, vaterite), calcium oxide, and calcium hydroxide from golden apple snail shells $[7,8]$. Until now, there have been no report on the preparation of calcium phosphates from golden apple snail shells. Only some calcium phosphates (dicalcium phosphate dihydrate, monocalcium phosphate monohydrate, tricalcium phosphate and hydroxyapatite) prepared from natural mineral resources such as cockle shells [8], oyster shells [9], sea urchin shells [10] and Mediterranean mussel shells [7] have been reported. Golden apple snail shells were recently used to produce nanocalcium carbonate [11], hydroxyapatite [12], while the shells of Pomacea lineate were also converted into hydroxyapatite bioceramic materials [13].

Our interest in calcium carbonate, monocalcium phosphate monohydrate $\mathrm{Ca}\left(\mathrm{H}_{2} \mathrm{PO}_{4}\right)_{2} \cdot \mathrm{H}_{2} \mathrm{O}$ (MCPM) and tricalcium phosphate $\mathrm{Ca}_{3}\left(\mathrm{PO}_{4}\right)_{2}(\mathrm{TCP})$ is due to their potential applications in various industries such as fertilizer production, animal feed mineral, catalyst in chromatography or gas sensor, water purification, food additive and drug carrier [14-18]. MCPM is used in large amount in Thailand as fertilizer, called superphosphate and animal feed mineral called P-21. TCP is widely used in medical field as medicine, tooth, bone, etc. Both compounds have been prepared with high chemical purities from various sources of calcium (calcium chloride, calcium carbonate, calcium oxide, calcium nitrate, etc.) and phosphorus (phosphoric acid, sodium phosphates, potassium phosphates, ammonium phosphates etc.) by many methods including chemical precipitation [19], sol-gel process [20], microwave method [21,22], pyrolytic synthesis [23], hydrothermal synthesis [24] and mechanochemical method [25-30]. However, these reported methods had complex procedures due to the need to control the temperature and/or $\mathrm{pH}$, prolong preparation time and specific quantity of raw agents, which raises the cost.

The aim of this study was to easily obtain calcium carbonate from golden apple snail shells and then subsequently use it to produce MCPM. The mixture of both compounds were heated to prepare TCP. All the prepared samples were characterized by thermogravimetric differential thermal analysis (TG/ DTG/DTA), X-ray fluorescence, X-ray diffraction, Fourier transform-infrared spectroscopy (and scanning electron microscopy. Chemical and physical properties of MCPM and TCP prepared from golden apple snail shells are reported for the first time. The preparation procedure herein is simple, rapid, inexpensive, friendly and less time consuming, which could be an interesting approach in recycling wastes and making value-added snail shells.

\section{EXPERIMENTAL}

Golden apple snail shells were obtained from Kalasin province, Thailand. They are normally collected about 10 tons per week after the community sends their meat to Talad Thai Market in Pathum Thani province. Transformation of golden apple snail shells to calcium carbonate included washing, drying, grinding, and then sieving through 100 mesh (Fig. 1). The obtained ground powder of golden apple snail shells was calcium carbonate.

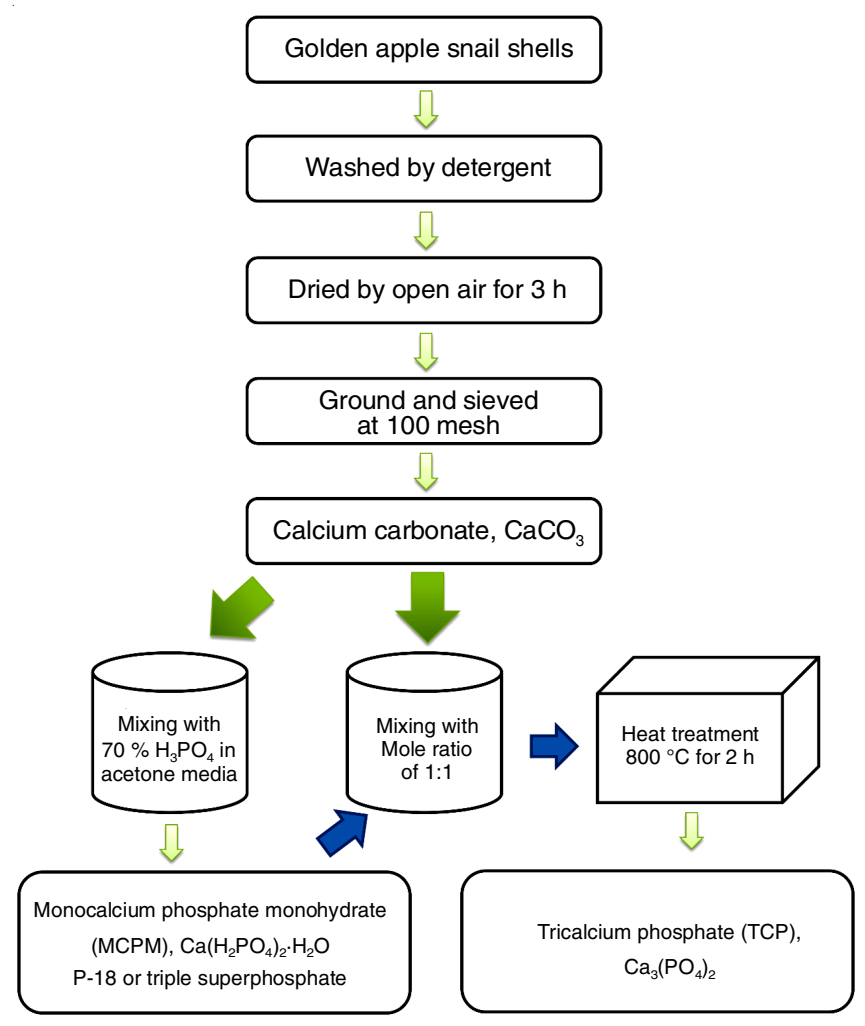

Fig. 1. Experimental procedure for the productions of $\mathrm{CaCO}_{3}$, $\mathrm{Ca}\left(\mathrm{H}_{2} \mathrm{PO}_{4}\right)_{2} \cdot \mathrm{H}_{2} \mathrm{O}$ and $\mathrm{Ca}_{3}\left(\mathrm{PO}_{4}\right)_{2}$

The synthesis procedure of monocalcium phosphate monohydrate and tricalcium phosphate consisted of two processes (Fig. 1). The first process was the preparation of MCPM as follows: $250 \mathrm{~mL}$ of acetone was added into $50 \mathrm{~g}$ of calcium carbonate powders, followed by continuous stirring with a magnetic stirrer, which resulted in a suspension. After that, $85 \mathrm{~mL}$ of $70 \%$ w/w $\mathrm{H}_{3} \mathrm{PO}_{4}$ was slowly added to the prepared suspension followed by vigorous stirring at ambient temperature for $15 \mathrm{~min}$ and the precipitates formed were aged for $30 \mathrm{~min}$ at room temperature, which resulted in powders. The obtained powders were washed three times with acetone until free from phosphate ions and then air-dried for $24 \mathrm{~h}$. The dried powders were referred to as the as-MCPM. The second process was the synthesis of TCP. The mixture of as-MCPM and calcium carbonate with $\mathrm{Ca} / \mathrm{P}$ ratio of 1.5 according to eqn. 1 was ground with a mortar. After thorough mixing, the resultant powders were calcined in a crucible in an electrical furnace at $800^{\circ} \mathrm{C}$ for $3 \mathrm{~h}$, which resulted in the calcined powder of TCP.

$$
\begin{aligned}
& \mathrm{Ca}\left(\mathrm{H}_{2} \mathrm{PO}_{4}\right)_{2} \cdot \mathrm{H}_{2} \mathrm{O}(\mathrm{s})+\mathrm{CaCO}_{3} \stackrel{800^{\circ} \mathrm{C}}{\longrightarrow} \\
& \mathrm{Ca}_{3}\left(\mathrm{PO}_{4}\right)_{2}(\mathrm{~s})+\mathrm{CO}_{2}(\mathrm{~g})+3 \mathrm{H}_{2} \mathrm{O}(\mathrm{g})
\end{aligned}
$$

Characterization of calcium carbonate, monocalcium phosphate monohydrate $\left[\mathrm{Ca}\left(\mathrm{H}_{2} \mathrm{PO}_{4}\right)_{2} \cdot \mathrm{H}_{2} \mathrm{O}\right]$ and tricalcium phosphate $\left[\mathrm{Ca}_{3}\left(\mathrm{PO}_{4}\right)_{2}\right]$, including phase identifications of the prepared powders was conducted using X-ray diffraction (XRD) (Philips PW3710, The Netherlands) with $\mathrm{CuK}_{\alpha}$ radiation $(\lambda=0.15406 \mathrm{~nm})$. Chemical composition was investigated by X-ray fluorescence. FTIR analysis of the prepared powders was performed using a Perkin-Elmer Spectrum GX FT-IR/ FT-Raman spectrometer. The FTIR spectra were recorded in 
the range of $4000-370 \mathrm{~cm}^{-1}$ using $\mathrm{KBr}$ pellets. The morphologies of the selected resulting samples were examined with Scanning Electron Microscope (SEM) using a LEO SEM VP1450 after gold coating.

\section{RESULTS AND DISCUSSION}

Table-1 listed the chemical composition and purity checked by XRF method and percentage yields of calcium carbonate, monocalcium phosphate monohydrate $\left[\mathrm{Ca}\left(\mathrm{H}_{2} \mathrm{PO}_{4}\right)_{2} \cdot \mathrm{H}_{2} \mathrm{O}\right]$ and tricalcium phosphate $\left[\mathrm{Ca}_{3}\left(\mathrm{PO}_{4}\right)_{2}\right]$. These results verify chemical formulae to be $\mathrm{CaCO}_{3}\left(\mathrm{Ca}: \mathrm{O}\right.$ ratio of 1.10:3.31), $\mathrm{Ca}\left(\mathrm{H}_{2} \mathrm{PO}_{4}\right)_{2} \cdot \mathrm{H}_{2} \mathrm{O}$ (Ca:P ratio of 1.00:2.05), and $\mathrm{Ca}_{3}\left(\mathrm{PO}_{4}\right)_{2}$ (Ca:P ratio of 1.47:1.00), which agree with theoretical information. For MCPM, the phosphorus content was found to be more than $21 \%$ without toxic elements according to standard control materials. Therefore, it can be used as feed mineral and food additive. Additionally, phosphorus pentoxide calculated for $\mathrm{Ca}\left(\mathrm{H}_{2} \mathrm{PO}_{4}\right)_{2} \cdot \mathrm{H}_{2} \mathrm{O}$, was found to be more than $56 \%$, which is similar to a superphosphate fertilizer. TCP was also produced with high percentage yield and without impurities of toxic agents, which is consistent with standard control materials, so the obtained compound can be used as food additive and in medical field.

Fig. 2 shows the XRD patterns of the prepared calcium carbonate, MCPM, and TCP samples, which are indexed and compared with the PDF standard data for each compound. Firstly, the XRD pattern of calcium carbonate shows a peak at $2 \theta=26.16^{\circ}$, corresponding to (111) reflections, which is indexed as $\mathrm{CaCO}_{3}$ with a structure comparable to the standard data of PDF \#752230 [27,28,31]. The result indicates that calcium carbonate crystal structure is aragonite phase of orthorhombic system with space group Pmcn. The XRD pattern of MCPM exhibits two sharp peaks at $2 \theta=23.71$ and $25.59^{\circ}$, corresponding to (020) and (-210) reflections and are indexed as $\mathrm{Ca}\left(\mathrm{H}_{2} \mathrm{PO}_{4}\right)_{2} \cdot \mathrm{H}_{2} \mathrm{O}$ with structure comparable to the standard data of PDF \#761822 [31], which indicates anorthic phase with space group $\mathrm{P} \overline{\mathrm{\tau}}$. Finally, the XRD pattern of TCP revealed maximum intensity peak at $2 \theta=31.02^{\circ}$, corresponding to (217) reflections, which are indexed as $\beta-\mathrm{Ca}_{3}\left(\mathrm{PO}_{4}\right)_{2}$ with structure comparable to the standard data of PDF \#702065, indicating rhombohedral crystal structure with space group R3c. From the XRD data of the prepared calcium carbonate, MCPM and TCP samples, no other characteristic peaks related to impurities and any intermediate materials are observed, which further confirm that the synthesized products are pure aragonite calcium carbonate MCPM, and TCP powders.

The FT-IR spectra of calcium carbonate, MCPM and TCP samples are presented in Fig. 3. FTIR spectrum of calcium carbonate shows fundamental vibration of $\mathrm{CO}_{3}{ }^{2-}$ anion as block unit in calcium carbonate structure [31]. There is a prominent absorption peak of $\mathrm{CO}_{3}{ }^{2-}$ at $1457 \mathrm{~cm}^{-1}$, which corresponds to

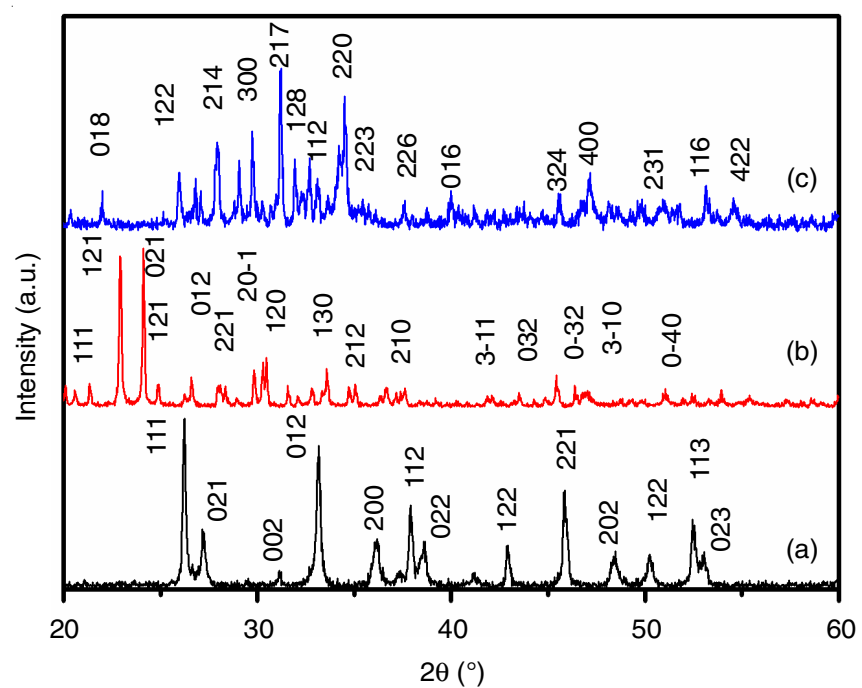

Fig. 2. XRD patterns of the prepared (a) $\mathrm{CaCO}_{3}$, (b) $\mathrm{Ca}\left(\mathrm{H}_{2} \mathrm{PO}_{4}\right)_{2} \cdot \mathrm{H}_{2} \mathrm{O}$ and (c) $\mathrm{Ca}_{3}\left(\mathrm{PO}_{4}\right)_{2}$

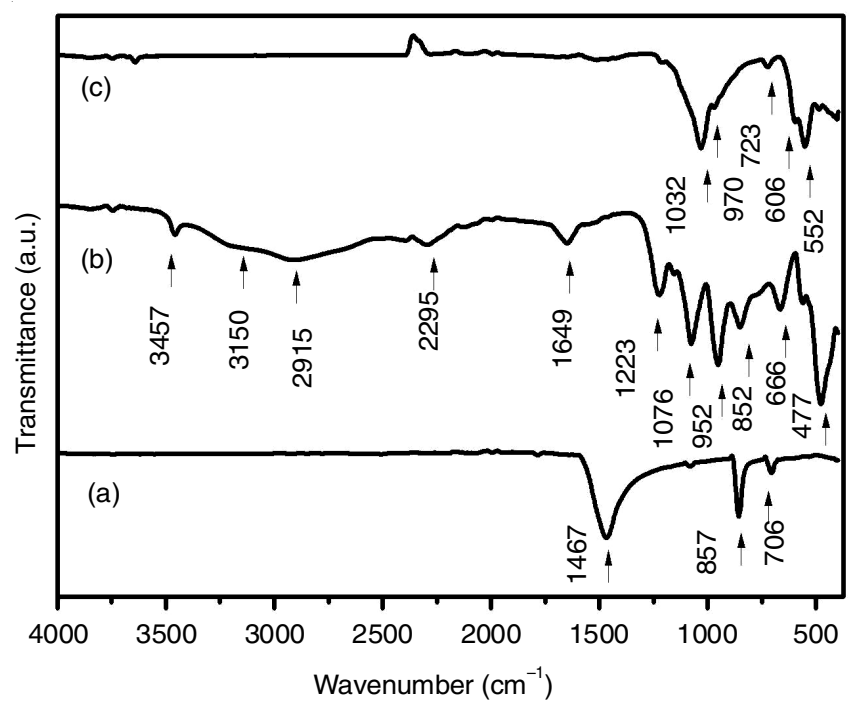

Fig. 3. FTIR spectra of the prepared (a) $\mathrm{CaCO}_{3}$, (b) $\mathrm{Ca}\left(\mathrm{H}_{2} \mathrm{PO}_{4}\right)_{2} \cdot \mathrm{H}_{2} \mathrm{O}$ and (c) $\mathrm{Ca}_{3}\left(\mathrm{PO}_{4}\right)_{2}$

the asymmetric stretching mode of $\mathrm{C}-\mathrm{O}$ bond. The appeared vibrational peaks at 1081,857 , and $706 \mathrm{~cm}^{-1}$ are assigned to the symmetric stretching mode of $\mathrm{C}-\mathrm{O}$ bond, out plane and in plane bending of $\mathrm{CO}_{3}{ }^{2-}$ anion, respectively. These vibrational modes define the $\mathrm{CO}_{3}{ }^{2-}$ of aragonite phase [4-6,26]. Fundamental vibration of $\mathrm{H}_{2} \mathrm{PO}_{4}{ }^{-}$anion and water molecules are observed in FTIR spectrum of MCPM. The strong bands in the region of $1150-950 \mathrm{~cm}^{-1}$ are attributed to the P-O stretching vibrations. The bending OPO vibrations appear in the region of 600-450 $\mathrm{cm}^{-1}$. The couple bands are assigned to the in plane P-O-H bending $\left(\mathrm{A}_{2}\right)$ and the out of plane bending $\left(\mathrm{A}_{1}\right)$ vibrations are

TABLE-1

CHEMICAL COMPOSITION, PURITY CHECKED BY XRF METHOD AND PERCENTAGE YIELDS OF CaCO $3, \mathrm{Ca}\left(\mathrm{H}_{2} \mathrm{PO}_{4}\right)_{2} \cdot \mathrm{H}_{2} \mathrm{O}$ AND $\mathrm{Ca}_{3}\left(\mathrm{PO}_{4}\right)_{2}$

\begin{tabular}{|c|c|c|c|c|c|c|c|c|c|c|c|}
\hline \multirow{2}{*}{ Samples } & \multicolumn{9}{|c|}{ Elemental content $(\%)$} & \multirow{2}{*}{$\begin{array}{c}\text { Purity } \\
(\%)\end{array}$} & \multirow{2}{*}{$\begin{array}{c}\text { Yield } \\
(\%)\end{array}$} \\
\hline & $\mathrm{Ca}$ & $\mathrm{P}$ & $\mathrm{O}$ & $\mathrm{Mg}$ & $\mathrm{Si}$ & $\mathrm{K}$ & $\mathrm{Cu}$ & $\mathrm{S}$ & $\mathrm{Fe}$ & & \\
\hline $\mathrm{CaCO}_{3}$ & 44.00 & 0.74 & 53.00 & 0.99 & 0.26 & 0.17 & 0.22 & 0.37 & 0.25 & 98.75 & 99.15 \\
\hline $\mathrm{Ca}\left(\mathrm{H}_{2} \mathrm{PO}_{4}\right)_{2} \cdot \mathrm{H}_{2} \mathrm{O}$ & 17.00 & 24.40 & 57.20 & 0.31 & 0.27 & 0.54 & 0.09 & 0.11 & 0.08 & 99.20 & 98.54 \\
\hline $\mathrm{Ca}_{3}\left(\mathrm{PO}_{4}\right)_{2}$ & 38.14 & 20.06 & 40.97 & 0.37 & 0.05 & 0.12 & 0.07 & 0.15 & 0.07 & 99.25 & 99.88 \\
\hline
\end{tabular}




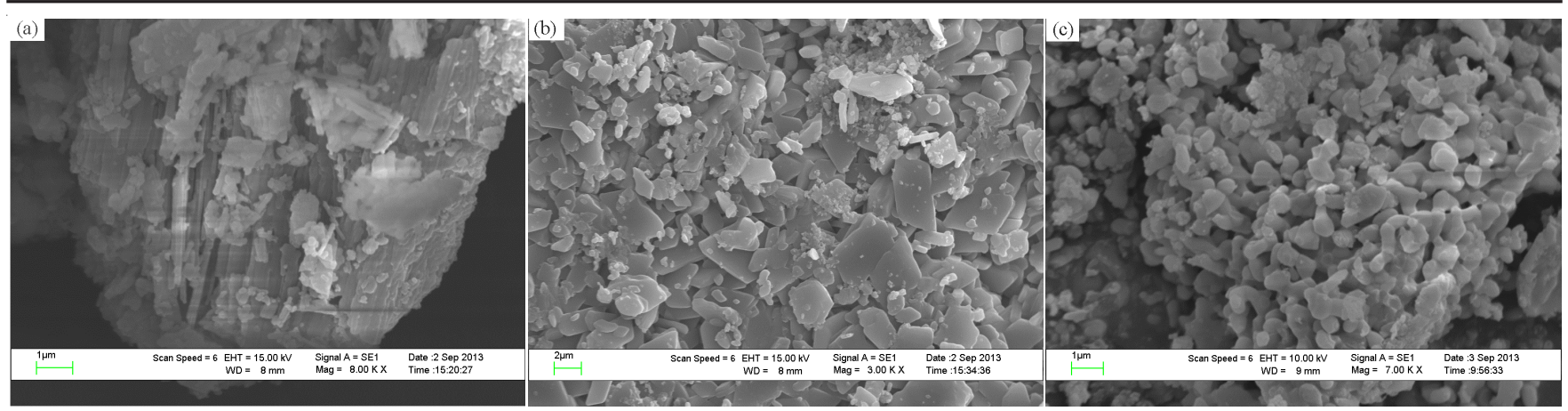

Fig. 4. SEM micrographs of (a) $\mathrm{CaCO}_{3}$, (b) $\mathrm{Ca}\left(\mathrm{H}_{2} \mathrm{PO}_{4}\right)_{2} \cdot \mathrm{H}_{2} \mathrm{O}$, and (c) $\mathrm{Ca}_{3}\left(\mathrm{PO}_{4}\right)_{2}$

observed at 1250 and $790 \mathrm{~cm}^{-1}$. A weak band occurred in the FTIR spectra at approximately $682 \mathrm{~cm}^{-1}$ is assigned to rocking mode involving water molecules. In the $\mathrm{O}-\mathrm{H}$ stretching mode region of $\mathrm{H}_{2} \mathrm{PO}_{4}^{-}$, characteristics for this compound appear as the A, B, C trio-bands at about 3180-3130 $\mathrm{cm}^{-1}$ (A band), 2440$2380 \mathrm{~cm}^{-1}$ (B band), and $18001670 \mathrm{~cm}^{-1}$ (C band). The question of the origin of $\mathrm{ABC}$ trio is responded in many studies on acidic salts, but an elucidation of this behaviour of strongly hydrogenbonded systems is yet to be determined [26]. One of the most favourable explanations of $\mathrm{ABC}$ trio advices a strong Fermi resonance between the $\mathrm{v}(\mathrm{OH})$ stretching fundamentals and the overtones $[2 \delta(\mathrm{OH})$ and $2 \gamma(\mathrm{OH})]$ or combinations involving the $\delta(\mathrm{OH})$ and $\gamma(\mathrm{OH})$ vibrations [32]. Usually, the $\mathrm{ABC}$ bands are very broad and include many well-resolved components. The vibrational bands of water molecules are related to three modes of bending, asymmetric stretching $(\mathrm{O}-\mathrm{H})$ and antisymmetric stretching $(\mathrm{O}-\mathrm{H})$, which appears at $1651 \mathrm{~cm}^{-1}\left(\mathrm{v}_{2}\right)$, $3242 \mathrm{~cm}^{-1}\left(v_{1}\right)$ and $3469\left(v_{3}\right) \mathrm{cm}^{-1}$, respectively $[19,26]$. For FTIR spectrum of the prepared TCP, vibrational bands are assigned to the fundamental vibrating unit, $\mathrm{PO}_{4}{ }^{3-}$ anion, which has four characteristic modes of vibration of a tetrahedral ion $\left(\mathrm{T}_{\mathrm{d}}\right)$ consisting symmetric stretching $\left(\mathrm{V}_{1}\left(\mathrm{~A}_{1}\right)\right.$; singly degenerate), anti-symmetric stretching $\left(\mathrm{V}_{3}\left(\mathrm{~F}_{2}\right)\right.$; triply degenerate), symmetric bending vibrations $\left(V_{2}(E)\right.$; doubly degenerate), and anti-symmetric bending $\left(\mathrm{V}_{4}\left(\mathrm{~F}_{2}\right)\right.$; triply degenerate) vibrations. Vibrational bands of $\mathrm{PO}_{4}{ }^{3-}$ anion for TCP product observed in the regions of 600-450 and $1000-900 \mathrm{~cm}^{-1}$ are assigned to the $\mathrm{v}_{4}\left(\mathrm{PO}_{4}^{3-}\right)$ and $\mathrm{v}_{3}\left(\mathrm{PO}_{4}{ }^{3-}\right)$ vibrations, respectively. Many peaks in this spectral region verify the existence of distinct nonequivalent phosphate units in each structure and the loss of degeneracy of the vibrational modes affecting factor group analysis. Additionally, the observation of a strong $v_{\mathrm{s}}(\mathrm{POP})$ bands $\left(723 \mathrm{~cm}^{-1}\right)$ is known to be the most striking feature of polyphosphate spectrum. The FTIR results of all the prepared samples obtained are consistent with the XRD data, which confirm the identification of each compound.

The SEM images of prepared calcium carbonate, MCPM and TCP products are shown in Fig. 4. The SEM micrograph of the prepared calcium carbonate (Fig. 4a) illustrates lumberlike crystals, which have many small and some large bark-like features on the surface. The SEM micrograph of the prepared MCPM (Fig. 4b) shows coalescence in aggregates of irregularly plate-shaped crystals of different sizes in the range of 0.40-2 $\mu \mathrm{m}$. Finally, the SEM micrograph of the TCP (Fig. 4c) shows coalescence in aggregates of non-uniform of polyhedral and spherical grains of different sizes and a porous structure appearing on its surface. The morphologies of the prepared calcium carbonate, MCPM and TCP particles may indicate further nucleation/growth of the nanocrystals inside the powder. The exact particle nucleation and growth mechanisms are still not clear. The size and shape of particles may be useful for specific applications of these compounds.

\section{Conclusion}

The large quantity of shells from a pest, golden apple snail, is a solid waste problem in Thailand, so this work has completely used these shells to produce valuable products [calcium carbonate, monocalcium phosphate monohydrate $\left(\mathrm{Ca}\left(\mathrm{H}_{2} \mathrm{PO}_{4}\right)_{2}\right.$. $\left.\mathrm{H}_{2} \mathrm{O}, \mathrm{MCPM}\right)$ and tricalcium phosphate $\left.\left(\mathrm{Ca}_{3}\left(\mathrm{PO}_{4}\right)_{2}\right), \beta-\mathrm{TCP}\right]$ with simple, rapid, low-cost and environmentally benign method. Phase impurities and chemical compositions of the prepared aragonite calcium carbonate, MCPM and $\beta$-tricalcium phosphate samples were confirmed by XRF, XRD, FTIR and SEM methods matching the standard of materials, which are crucial for specific applications. These reported data have great potential to be used in the industry for large-scale production of aragonite calcium carbonate, MCPM and $\beta$-tricalcium phosphate from golden apple snail shell to apply as feed mineral, food additive and medicine in the future, which is a way of sustainable development.

\section{ACKNOWLEDGEMENTS}

This work is supported by The Thailand Research Fund (TRF) (RDC5940004-M02).

\section{CONFLICT OF INTEREST}

The authors declare that there is no conflict of interests regarding the publication of this article.

\section{REFERENCES}

1. S. Basumatary, Res. J. Chem. Sci., 3, 95 (2013).

2. T.S. Sin, Crop Prot., 25, 1004 (2006); https://doi.org/10.1016/j.cropro.2006.01.012.

3. A. Birla, B. Singh, S.N. Upadhyay and Y.C. Sharma, Bioresour. Technol., 106, 95 (2012);

https://doi.org/10.1016/j.biortech.2011.11.065.

4. P.-L. Boey, G.P. Maniam, S.A. Hamid and D.M.H. Ali, Fuel, 90, 2353 (2011);

https://doi.org/10.1016/j.fuel.2011.03.002.

5. S. Hu, Y. Wang and H. Han, Biomass Bioenergy, 35, 3627 (2011); https://doi.org/10.1016/j.biombioe.2011.05.009. 
6. M.R.R. Hamester, P.S. Balzer and D. Becker, Mater. Res., 15, 204 (2012); https://doi.org/10.1590/S1516-14392012005000014.

7. I.J. Macha, L.S. Ozyegin, J. Chou, R. Samur, F.N. Oktar and B. BenNissan, J. Aust. Ceram. Soc., 49, 122 (2013); http://hdl.handle.net/10453/23750.

8. K.N. Islam, M.Z.B.A. Bakar, M.M. Noordin, M.Z.B. Hussein, N.S.B.A. Rahman and M.E. Ali, Powder Technol., 213, 188 (2011); https://doi.org/10.1016/j.powtec.2011.07.031.

9. H. Onoda and H. Nakanishi, Nat. Resour., 3, 71 (2012); https://doi.org/10.4236/nr.2012.32011.

10. H. Onoda, M. Ichimura and A. Takenaka, Phosphorus Res. Bull., 24, 49 (2010); https://doi.org/10.3363/prb.24.49.

11. N. Rungpin, S. Pavasupree, P. Prasassarakich and S. Poompradub, Polym. Compos., 36, 1620 (2015); https://doi.org/10.1002/pc.23070.

12. J.N. Putro, N. Handoyo, V. Kristiani, S.A. Soenjaya, O.L. Ki, F.E. Soetaredjo, Y.-H. Ju and S. Ismadji, Ceram. Int., 40, 11453 (2014); https://doi.org/10.1016/j.ceramint.2014.03.162.

13. S.M. de Paula, M.F.G. Huila, K. Araki and H.E. Toma, Micron, 41, 983 (2010); https://doi.org/10.1016/j.micron.2010.06.014.

14. H. Onoda, R. Matsumoto and M. Tafu, Int. J. Environ. Prot., 3, 1 (2013).

15. S.R. Paital and N.B. Dahotre, Mater. Sci. Eng. Rep., 66, 1 (2009); https://doi.org/10.1016/j.mser.2009.05.001.

16. N. Viriya-empikul, P. Krasae, B. Puttasawat, B. Yoosuk, N. Chollacoop and K. Faungnawakij, Bioresour. Technol., 101, 3765 (2010); https://doi.org/10.1016/j.biortech.2009.12.079.

17. M. Vallet-Regi and J.M. Gonzalez-Calbet, Prog. Solid State Chem., 32, 1 (2004); https://doi.org/10.1016/j.progsolidstchem.2004.07.001.

18. D. Jiang and J. Zhang, Curr. Appl. Phys., 9, S252 (2009); https://doi.org/10.1016/j.cap.2009.01.029.

19. B. Boonchom, J. Alloys Compd., 482, 199 (2009); https://doi.org/10.1016/j.jallcom.2009.03.157.
20. L. Gan and R. Pilliar, Biomaterials, 25, 5303 (2004); https://doi.org/10.1016/j.biomaterials.2003.12.038.

21. N. Rameshbabu and K.P. Rao, Curr. Appl. Phys., 9, S29 (2009); https://doi.org/10.1016/j.cap.2008.08.018.

22. A. Ioitescu, G. Vlase, T. Vlase and N. Doca, J. Therm. Anal. Calorim., 88, 121 (2007); https://doi.org/10.1007/s10973-006-8022-3.

23. M. Minamisawa, S. Yoshida and A. Uzawa, Powder Technol., 230, 20 (2012); https://doi.org/10.1016/j.powtec.2012.06.034.

24. R. Xin, F. Ren and Y. Leng, Mater. Des., 31, 1691 (2010); https://doi.org/10.1016/j.matdes.2009.01.048.

25. T.M. Volkmer, F. Lengler, O. Barreiro, V.C. Sousa and L.A. dos Santos, Powder Technol., 235, 599 (2013); https://doi.org/10.1016/j.powtec.2012.10.025.

26. C.-K. Hsu, Mater. Chem. Phys., 80, 409 (2003); https://doi.org/10.1016/S0254-0584(02)00166-9.

27. B. Mirhadi, B. Mehdikhani and N. Askari, Process Appl. Ceram., 5, 193 (2011); https://doi.org/10.2298/PAC1104193M

28. C. Zou, K. Cheng, W. Weng, C. Song, P. Du, G. Shen and G. Han, J. Alloys Compd., 509, 6852 (2011); https://doi.org/10.1016/j.jallcom.2011.03.158.

29. B. Li, X. Chen, B. Guo, X. Wang, H. Fan and X. Zhang, Acta Biomater., 5, 134 (2009); https://doi.org/10.1016/j.actbio.2008.07.035.

30. Y. Li, T. Wiliana and K.C. Tam, Mater. Res. Bull., 42, 820 (2007); https://doi.org/10.1016/j.materresbull.2006.08.027.

31. J. Xu, D. F.R. Gilson and I. S. Butler, Spectrochim. Acta A, Mol. Biomol. Spectrosc., 54, 1869 (1998); https://doi.org/10.1016/S1386-1425(98)00152-8.

32. V. Videnova-Adrabinska, J. Mol. Struct., 177, 477 (1988); https://doi.org/10.1016/0022-2860(88)80114-5. 